\title{
REGIONAL BUDGETS: TIGHTENING OUR BELTS ${ }^{1}$
}

\section{A.Deryugin}

Even lower growth rates of budget expenditure offset relatively low revenue growth rates of the consolidate regional budgets which gradually becomes the main tool for ensuring regional and local budgets balance and so far allows keeping debt level under control. Regional budgets execution is under major strain in relatively poor regions which face a significant contraction of revenues.

According to preliminary data in intervening ten months of 2015, consolidated budgets of the constituents of the Russian Federation came to $106.4 \%$ against the same period of last year ${ }^{2}$ (Fig. 1). Solely seven constituents of the Russian Federation have registered this indicator above the inflation level in the course of twelve months (15.6\%): in Lipetsk region (116.8\%), Leningrad region (118.3\%), Karachaevo-Cherkessk Republic (115.9\%), Republic of Tatarstan (116.0\%), Khanty-Mansiisk Autonomous district - Yugra (122.8\%), Sakhalin region (151.2\%) and Chukotka Autonomous district (136.2\%). In the meantime, the consolidated budgets revenues of twenty-six regions have failed to reach last year level.

In September-October 2015, regional consolidated budgets revenues varied respectively - by 8.9\% (September 2015 against September 2014) and $-5.6 \%$ (October 2015 against October 2014). On the whole as of the periodend for $\mathrm{H} 2$ (since July to October 2015), revenues increment barely came to $0.6 \%$. Maintaining such low revenues growth until the end of the fiscal year can result in setting another "record" by real revenues volume. Previous record was set in $2014-12.2 \%$ of GDP (by average $13.8 \%$ over recent ten years).

Volatility of the proceeds generated by the corporate income tax whose rates in September-October constituted $141.8 \%$ and $97.5 \%$, respectively, explain high volatility of the regional consolidated budgets revenue (Fig. 1). Thereby, proceeds generated by the corporate income tax have gone up following significant contraction posted in July-August to $66.6 \%$ and $82.5 \%$ compared to the corresponding period of last year. Reviewing the whole period since the start of the year, as of the period-end

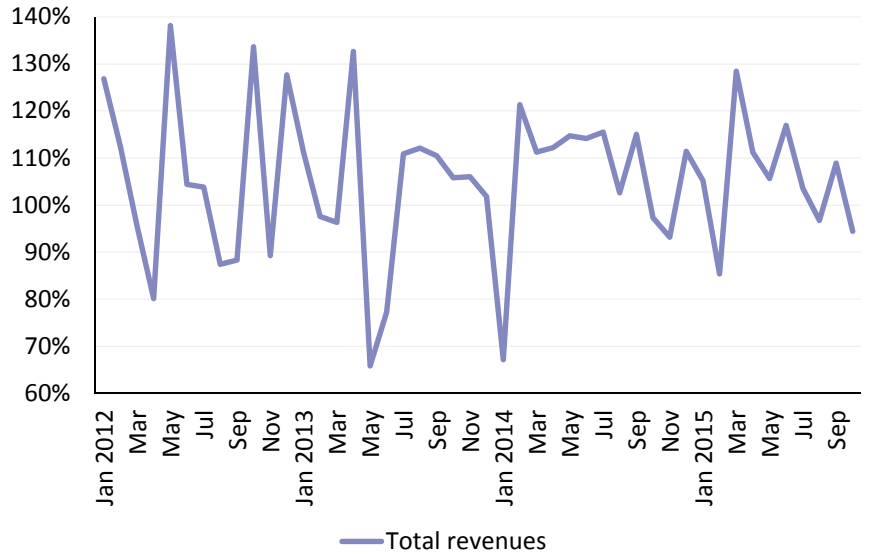

Source: calculated on data released by Federal Treasury.

Fig. 1. Growth rates of total revenues of consolidated budgets of RF constituents, \% to same indicator last year

1 This paper was originally published in Online Monitoring of Russia's Economic Outlook No.16.

2 Hereinafter, unless otherwise specified, all given data without account of regions of Crimean federal district. 
for ten months their growth came to $111.7 \%$ ( $107.7 \%$ minus Sakhalin region) which is above the total revenue growth rates (Fig. 2).

Volatility of proceeds from the corporate income tax is due to the fact that the tax base has been hardly predictable since the turn of the year.

Such disparity is very noticeable in certain regions: even year-to-date proceeds generated by this tax vary greatly from $24.6 \%$ in the Republic of Mordovia to $307.1 \%$ in the Byriat Republic. Taking account of the fact that the corporate income tax accounts for a quarter of the total volume of the consolidated budgets revenues of the constituents of the Russian Federation, its volatility affects total projected budget revenues which makes regions overcautious regarding budget planning and execution.

Other major regional and local budgets revenues grew below the corporate income growth rates. Rather stable personal income tax following a slight splash registered in June-August when it demonstrated growth rates at no less than $105.0 \%$ has lost its momentum barely adding in September-October 3.9\% and

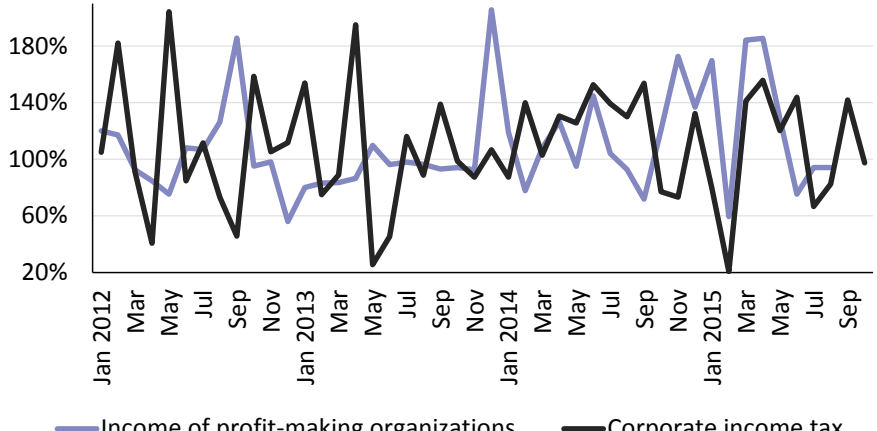

Source: authors'calculation on data released by Federal Treasury and Rosstat.

Fig. 2. Income growth rates of profit-making organizations and profit tax proceeds, \%

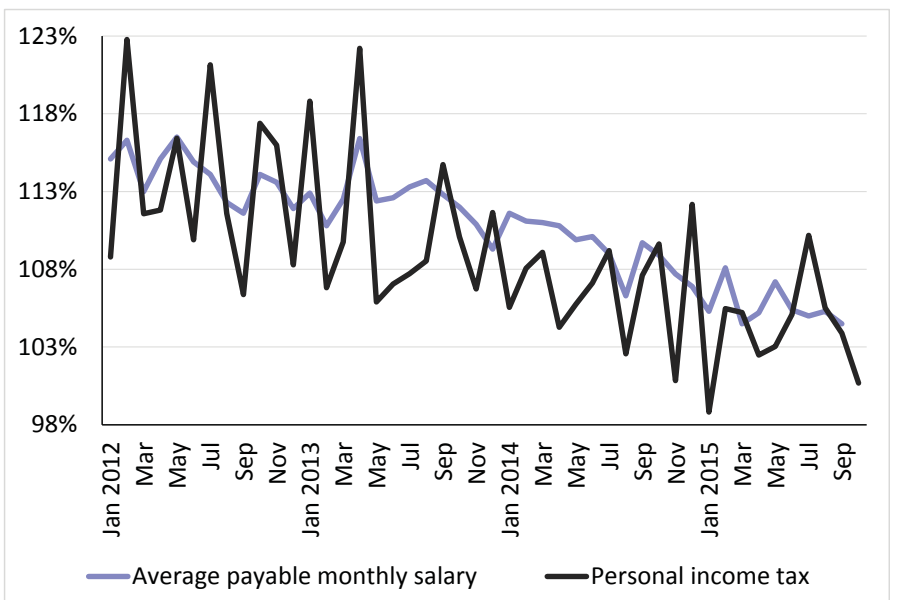

Source: authors'calculation on data released by Federal Treasury and Rosstat.

Fig. 3. Growth rates of personal income tax and average monthly nominal salary, \%

$0.7 \%$, respectively against last year nominal values. Overall, this corresponds to the payroll growth slowdown (Fig. 3).

In October 2015, solely excises demonstrated growth rates of $114.9 \%$ among other main revenue sources. Meanwhile, corporate property tax (70.8\%), non-tax proceeds (99.5\%) and non-repayable transfers from other budgets $(81.3 \%)$ have failed to reach the last year level ensuring general negative dynamics of the consolidated budgets revenues.

It is unlikely that outlook will drastically swing until the end of current fiscal year. Regional budgets revenues growth rates will be determined by the current trends observed in the growth rates of corresponding tax bases which recently have not been demonstrating upward trends. Tax revenues will not be fully assisted by the federal budget transfers whose volume according to the Federal budget Law shall contract by $12.3 \%$ by yearend against last year.

Despite high level of inflation as well as the need to fulfill "May decrees" of the President which envisage wages and salaries growth for a wide category of budget sphere employees, contraction of the revenue base both of regional and local budgets and financial assistance from the federal budget, uncer- 
tainty with the estimates of corporate income tax proceeds and reduced possibilities to attract borrowings are pushing regions to tighten their fiscal policy. For example, regional consolidated budgets expenditure growth as of the period-end for ten months has come to barely $102.5 \%$ and in SeptemberOctober $2015-94.8 \%$ and $86.8 \%$ against the same months last year.

Current surplus of budget revenues growth over budget expenditure has kept at bay public debt growth. Over the period from January to September 2015 , it has gone up by $4.0 \%$ in absolute terms. However, as a rule debt grows in the course of December together with a drastic increment of expenditure. In 2013 and 2014, debt growth over first nine months did not exceed 4.1\% and as of the yearend hiked by $28.6 \%$ and $20.2 \%$, respectively.

Regional public debt pattern remains on hold: credit organizations loans and budget loans constitute $36.7 \%$ and $37.8 \%$ of the total volume. Increase of the volume of budget loans granted to regions aimed at fighting crisis since the start of the fiscal year has somewhat phased out credit organizations' loans (as of early October their share fell from $42.5 \%$ to $37.6 \%$, and a share of budget loans went up from $31.0 \%$ to $37.3 \%$ ). This made debt service relatively cheaper. On the other hand, we can expect recovery in a share of commercial loans by yearend unless the government takes a decision to allocate additional transfers or budget loans to regions envisaged in the federal budget for the current year. There will be a shortage of funds to cover December deficit which will result in the recovery of commercial loans share.

In 2014, events were evolving according to this scenario. It should be noted that contraction of the proceeds generated by the corporate income tax to a greater extent related to relatively poor regions. Taking into account the fact that redistribution of adjustment transfers (subsidies to level fiscal capacity of the RF constituents) executed with the help of retrospective indices of tax bases will lead to somewhat understatement of financial assistance against the level they would have been calculated parting from the current tax base or current real tax revenues. In the wake of the crisis, this feature of the methodology of subsidies redistribution which serves as an incentive for economic development will trigger additional deterioration in poor regions. 